\title{
CREATING KNOWLEDGE TOGETHER WITH YOUR CUSTOMERS - THE CASE OF EARLY CUSTOMER INTEGRATION (ECI) INTO THE INNOVATION PROCESS
}

\author{
CHRISTOPH H. WECHT \\ Institute of Technology Management, University of St. Gallen, \\ Dufourstrasse 40a, 9000 St. Gallen, Switzerland \\ E-mail: christoph.wecht@unisg.ch
}

\begin{abstract}
In the current diverse and dynamic business environment, customer contributions can improve the effectiveness of product innovation activities. Consequently, companies engage in numerous initiatives to get closer to their customers or involve them directly in their innovation processes. In this analysis of European high-tech companies, the author focuses on the innovation front-end, since during the early stages of the innovation process, customer consideration can greatly affect innovation success. Using specific manufacturer goals for early customer integration (ECI) as starting point, the author derives necessary customer contributions, then develops a conceptual framework for joint knowledge creation between manufacturer and customer. Four new customer roles enhance the well-known Lead User approach: opportunity sensor, complementary specialist, specifier, and selector. Using this foundation, the paper analyses the respective characteristics and managerial challenges of these ECI roles.
\end{abstract}

\section{Introduction}

Innovation — especially radical innovation — leads to higher profits. Consequently, the ability to bring new product ideas to market represents the success factor par excellence in the modern dynamic environment (Kim and Mauborgne 1997). However, most innovative ideas fail because of their technical weaknesses, competitive disadvantages, non-reflected me-too strategies, and, most critically, lack of market orientation (Jaworski and Kohli 1993; Atuahene-Gima 1995; Atuahene-Gima 1996; Lukas and Ferrell 2000; Kahn 2001). This lack of a market orientation in new product development (NPD) often results in overengineered products that misfit customer needs.

As a result, the role of customers as sources of innovation has become more and more important for both the marketing side of a company, where customers have taken on a growing number of traditional marketing tasks (Kotler, Jain et al. 2002), and early NPD activities by R\&D, where customer input has achieved the greatest leverage. In other words, customer integration is relevant not only for the "market-pull" but also the "technologypush" side of innovation. The positive influence of active customer involvement in the innovation process has been demonstrated by several empirical studies (cf. Bacon and Beckman 1994; Murphy and Kumar 1996; Murphy and Kumar 1997; Gruner and Homburg 1999; Kristensson, Magnusson et al. 2002), which show that such integration leads to the more successful product portfolio needed for profitable growth in the marketplace. 
Especially during early NPD activities, or the front-end, during which up to 85 percent of the total costs of NPD are assigned (Gebhardt 1996; Buergel and Zeller 1997), customer integration leads to the increased effectiveness of innovation activities. The best empirically validated concept for this field, and one of the very few available, is the Lead User concept by Eric von Hippel (cf. von Hippel 1976; von Hippel 1978; von Hippel 1986; von Hippel 1988). With its focus on integrating customers into NPD for new product idea generation, the Lead User concept requires a rare type of customers and does not explore their full innovation capability, which may be beneficial for NPD beyond the generation of new product ideas. In addition, some studies indicate that early, intense customer integration does not necessarily lead to the success of a firm's innovation process (cf. Atuahene-Gima 1995; Ernst 2001; Henard and Szymanski 2001). Studies of discontinuous product development projects suggest that most companies do not employ a formal, highly structured procedure, neither for idea generation and development nor for customer integration (Christensen 1997). Although firms follow consistent processes during NPD, these processes differ significantly from those deployed for incremental projects.

In response, this paper contributes to the discourse on early customer integration in two ways. First, it affirms evidence that thoroughly executed customer integration into NPD can be beneficial for a company's innovation performance. Second, it addresses a deficit in the existing body of literature, namely, the almost complete lack of empirical studies that focus on specific customer contributions during the early NPD phases. In addition to the Lead User approach, there are several other relevant methods for integrating customers into the innovation front-end. The paper derives these methods by asking how manufacturers' goals and objectives influence the decision about and management of the specific shapes of early customer integration. In turn, the paper provides a close look at the roles customers can take (or be assigned to) and the contributions they can deliver. The findings lead to a typology and corresponding managerial implications for customer integration that are based on the manufacturer's goals and customers' contributions.

The experimental nature of this research requires a qualitative case study approach so that we may gain a holistic understanding of the underlying cultural systems at work (Stake 1988; Yin 1994). We employ an iterative learning process in which we consider input from both empirical and theoretical data. In the empirical data collection, we began with real-life problems that we subsequently developed into in-depth case studies with which we attempt qualitatively to explain successful ECI practices. That is, we study many cases in detail to attain an in-depth understanding of the natural setting, the complexity, and the context (cf. Punch 1998). This empirical data collection occurred in a research project that ran from August 2002 to April 2004. The project concentrated on all aspects of ECI and investigated 18 companies, selected on the basis of their highly developed customer integration processes: Ascom, Bayer, Büchi Labortechnik, EADS Astrium, Endress+Hauser Flowtec, 
Hilti, IVF Hartmann, Mammut Sports Group, Model, MTU Aero Engines, Philips, Rieter Textiles, SBB Schweizerische Bundesbahnen, Sefar, Siemens, SIG, Syngenta, and Zumtobel Staff. All the selected companies are based in Germany, Liechtenstein, Switzerland, or The Netherlands, but they spread across various industries and range from small enterprises to large multinationals. By maximizing the differences among the cases, we control for idiosyncratic influences in each case and provide at least some basis for generalization. In addition, similarities in management practices across diverse ECI activities indicate a relationship exists between practice and outcomes (cf. Lynn, Morone et al. 1996).

Data collection took place during 42 semi-structured research interviews with senior representatives from $\mathrm{R} \& \mathrm{D}$, marketing, and product management, as well as with customers of the investigated companies. The interview data were complemented by desk research and analyses of corporate and annual reports, company presentations, and company journals. In follow-up sessions with selected interview partners, we validated our findings and interpretations for each company.

\section{Early Customer Integration (ECI)}

Similar to early supplier involvement upstream in a value chain, we refer to the early involvement of customers in the innovation process as early customer integration (ECI). We define ECI as the integration of customers, customers' customers, or intermediaries to customers (in short, any actor on the downstream side of the value chain) into the front-end of the innovation process, characterized by an active customer role (e.g., surveys, interviews). The well-known Lead User approach (von Hippel 1976; von Hippel 1988) fits well in this definition. Unlike the previously describe approaches, which aim at collecting knowledge about customers, ECI centralizes knowledge from customers. The underlying rationale is that, by giving customers an active role, a firm can integrate them into the frontend. In addition, it includes all phases of the front-end (cf. Bacon and Beckman 1994; Koen, Ajamian et al. 2001; Kim and Wilemon 2002; Herstatt and Verworn 2003) and can be divided into different modes, each characterized by different customer contributions and roles and requiring specific activities from the manufacturer. A manufacturer integrates customers into the early phases of its innovation process to increase process effectiveness and achieve better results; that is, the overall goal is to improve innovation process output with the help of selected customers. In general, a manufacturer can do so by developing more or better ideas or ideas with higher market and business potential (cf. von Hippel 1988; Lilien, Morrison et al. 2002; Lettl 2004).

Currently, however, no studies address the effects of manufacturers' expectations regarding specific customer roles in the innovation front-end. Therefore, we focus specifically on the goals and expectations that motivate manufacturers to run ECI. In addition, the only literature that considers the expected outcome of integration employs a 
generic, unspecific level and fails to observe roles and managerial implications. We therefore fill that research gap by showing that goals and results are determining factors that enable us to differentiate between specific modes of ECI and to carve out appropriate managerial instruments.

\section{Manufacturers' Goals and Integration Results}

Using clear, specific goals, the manufacturer should open its innovation process to enable customers to take an active role and contribute according to their abilities and knowledge. Therefore, this section aims specifically to develop a typology of ECI modes that is based on manufacturers' goals and expected results, then characterize those modes more precisely with the respective customer roles and contributions.

The outcome of ECI consists of closely related components: manufacturer's goals, customers' roles, and customers' contributions. The manufacturer's goals represent the beginning of the chain of influence that leads to ECI results. On the basis of these goals, customers must play different roles and deliver different contributions. With the proper customer contributions, the overall ECI result should lead to the desired improvement in the innovation output, which can be compared with the manufacturer's original goals. We use the manufacturer's goals, expectations, and customer integration results synonymously. Because we do not measure the integration's success rates, we do not distinguish between expected and achieved results. Focusing on the specific results expected from ECI represents a challenging task for further research that could identify the success rates of different result-based modes of ECI and, if they differ as we expect, explain the discrepancy. The principal goal of customer involvement in general and ECI in particular is improving the company's innovation success rate along with the necessary increasing R\&D expenditures and high new product failure rates. That is, the manufacturer expects advantages that outweigh the unavoidable increase in complexity that ECI demands (cf. Kirchmann 1994; Brockhoff 2002). Existing studies list various advantages (i.e., manufacturer's goals) that can be clustered into groups. After eliminating redundancy, we find we can group the relevant subjects into three paramount objectives, as we show in Table 1 (Kirchmann 1994; Gruner 1997).

From a macro perspective, $R \& D$ cooperation, such as customer integration, exists for several reasons (Gerpott 1998), including the reduction of resources and cost needed to establish a technological innovation, an increase in quality and speed on the way to R\&D results, the reduction of technological and financial risk, and the preparation for new market segments (cf. Rotering 1990; Kirchmann 1994; Teichert 1994; Sakakibara 1997). Generally, these reasons match the goals of customer integration quite closely. For our purposes, however, the micro level is more effective. Bruce and Biemans (1995), for example, identify the following potential results of customer integration into the innovation process: 
- Generation of new product ideas,

- Availability of information regarding customer needs,

- Feedback on concepts and prototypes,

- Aid during development, and

- Assistance during innovation marketing.

Whereas assistance during development and innovation marketing are outside the frame of ECI, and therefore will not be considered herein, the remaining contributions serve as starting points for our subsequent elaboration.

\section{Result-Oriented Customer Roles During ECI}

Using manufacturer goals and customer contributions as the determinants, we have developed a basic ECI framework, which we use to identify the following distinct customer roles: (1) opportunity sensor, (2) complementary specialist, (3), specifier, and (4) selector.

Figure 1 gives an overview of these customer roles and relates them to the Lead User approach. The Lead User (von Hippel 1976; von Hippel 1988) appears in the middle of ECI, because it represents the prototype of early and active customer integration. In the Lead User approach, customers are selected to generate new solutions on the basis of their innovative need profile; that is, they are ahead of the main market. In addition, they must possess a certain technological expertise, as their ability to develop their own prototypes to solve their problems demonstrates. Tacit knowledge dominates, and the joint innovation process between the manufacturer and the Lead User stresses knowledge conversion as means for new knowledge generation. 


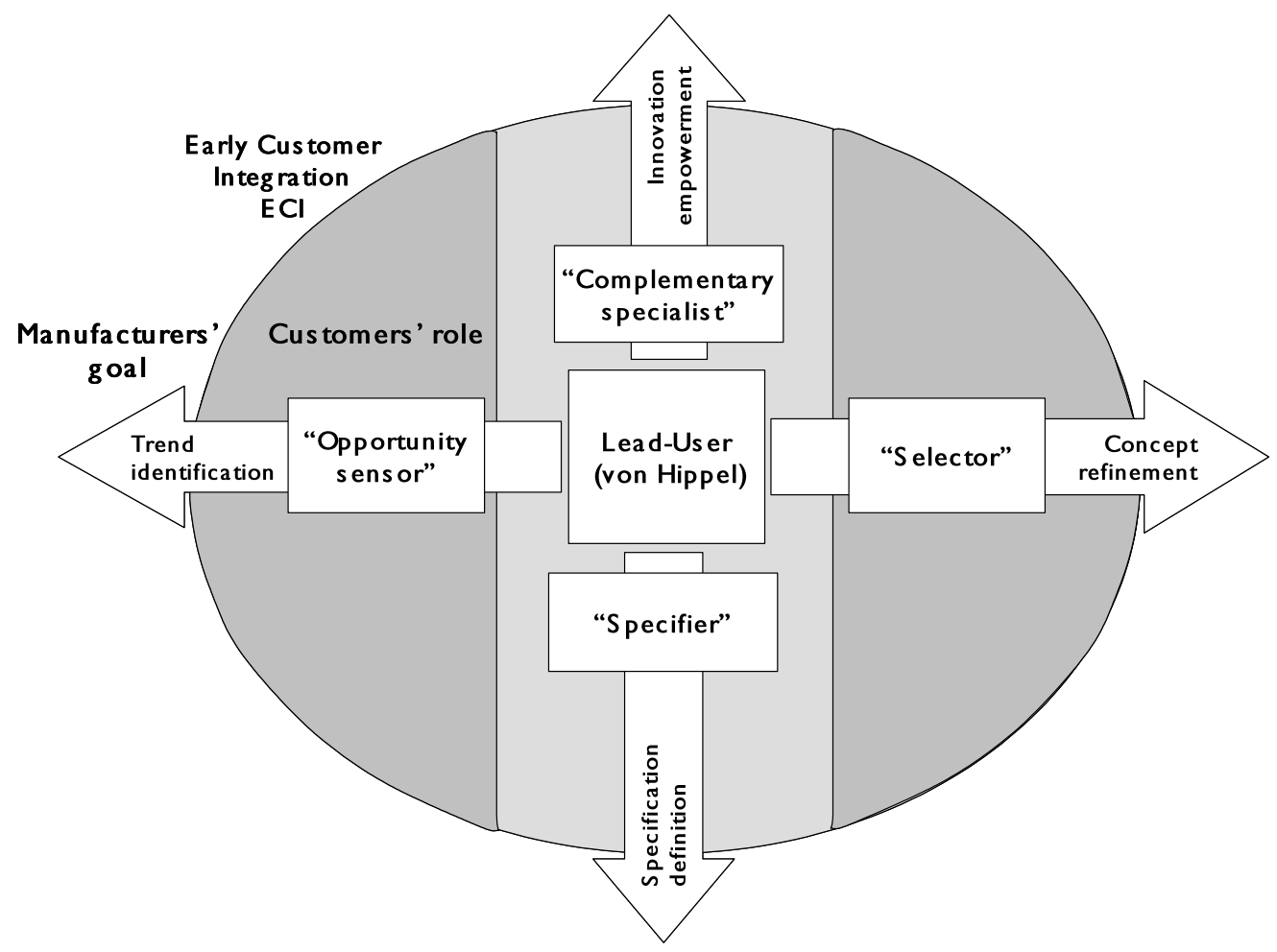

Figure 1: Customer roles during early customer integration ECI

The drivers obtained from the preceding analysis - chance orientation, creation orientation, and solution orientation - determine the starting positions for the new customer roles, which complete the ECI picture. For this analysis, we provide a short overview of the differentiating elements that determine the customer roles and separate them from the Lead User role, including concrete innovation elements for which customers are considered, the contribution of the customer to NPD, and the type of customer knowledge.

Regardless of the specific model or structure applied to the innovation process, three distinct elements always can be identified: Each prototypical innovation process consists of an idea-generation phase, an idea-materialization phase, during which the generated ideas are developed and specified, and finally a value realization, or idea-commercialization, phase during which the new ideas are brought to market (cf. Cooper and Kleinschmidt 1988; Gerpott 1998; Koen, Ajamian et al. 2001). Some authors have focused on customer contributions and identified similar steps during the development of new products (e.g., 
problem identification, drafting of problem solutions, and realization of the selected solution (Kleinaltenkamp and Dahlke 1998), problem identification and idea formulation, development, and realization (Kirchmann 1994). The characteristics of these basics steps make it possible to derive the necessary contributions of general and specific customer input for ECI. However, most existing studies consider the role of customers as information sources without detailing their specific innovation contribution.

For a deeper understanding of customer roles, the knowledge perspective of innovation is also helpful. The creation of new knowledge is the central theme of the NPD process (Leonard-Barton 1995; Madhavan and Grover 1998), and depending on the customer's role, different types of knowledge are generated. One level builds on the classic differentiation between tacit and explicit knowledge (cf. Nonaka and Takeuchi 1995), whereas the other uses the distinction between market- and technology-related content (cf. Gassmann and Gaso 2004). Furthermore, from knowledge creation in general, we can identify the two broad types of knowledge acquisition and knowledge conversion (Huber 1991; Nonaka and Takeuchi 1995). The identified customer roles in ECI fit the underlying innovation process steps and demonstrate different characteristics, according the nature and creation of new knowledge.

\subsection{Opportunity Sensor}

The opportunity sensor role deals mainly with problem identification or idea generation by concentrating on trends and scenarios that may lead to new opportunities and chances. The type of knowledge involved is market related and tacit. Depending on the concrete ECI setup, the knowledge creation mode could be either acquisitive (e.g., collecting specific customer knowledge about new competitor offerings) or transforming (e.g., jointly developing new scenarios with customers). In this ECI mode, the specific contribution the customer delivers, other than its needs, entails information about the latest trends, new technologies, and new market developments.

For the next three roles, the main focus lies on the further development of ideas and drafting problem solutions. Innovative, leading-edge customers deliver highly specified technological knowledge in addition to their inherent proficiency about their needs and requirements. Thus, the creation of new knowledge through the collaboration with the manufacturer is key and requires sensitive customers.

\subsection{Selector}

At the end of the innovation front-end process, new concepts must be fed into the NPD process. At this stage, an integrated customer can build on its user experience with existing products and help select and refine promising product concepts or prototypes. Tacit 
customer knowledge converts into feedback and increases the manufacturer's chance to develop a successful new product.

\subsection{Complementary Specialist}

Explicit knowledge in a field complementary to the core competence of the manufacturer represents the main asset of complementary specialists, who may provide either specific market knowledge or product-related expertise in fields such as styling or production. The focus for this mode lies mostly on the combination, and resultant conversion, of existing tacit knowledge to create innovative solutions that push the envelope of the manufacturer's innovation capabilities.

\subsection{Specifier}

This specific role also is grounded in the integration of customers with deep expert knowledge in the manufacturer's competence field. This knowledge enables the customer not only to push and steer innovation through product specification but also to take a leading role in the integration process (from the customer's perspective, the same process might be regarded as supplier integration). The required level of knowledge exceeds that typical for the Lead User approach and limits the number of cases for which this approach should be chosen.

\subsection{Lead User}

This customer role is located right in the middle of ECI being the prototype of early and active customer integration. Customers are selected for the generation of new solutions based on their 'innovative need profile', i.e. being ahead of the main market. In addition a certain technological expertise is needed expressed by the fact that some Lead users even develop their own prototypes to solve their problems. Once again tacit knowledge is dominating and the joint innovation process stresses the importance of knowledge conversion.

Within the body of knowledge customers may provide application knowledge within the main technological competence field of the manufacturer characterizes the customer role of Lead User. Von Hippel (1986) stated that a customer (user of a certain product) can be crucial for the fast and successful development of innovative products. In this context Lead users are described as customers that face needs that will be general in a marketplace - but face them months or years before the bulk of that marketplace encounters them - and are positioned to benefit significantly by obtaining a solution to those needs. 
Figure 2 provides an overview of these customer roles, illustrated with specific company examples.

\begin{tabular}{|c|c|c|c|c|c|}
\hline & $\begin{array}{l}\text { Opportunity } \\
\text { sens or }\end{array}$ & Selector & $\begin{array}{c}\text { Complimentary } \\
\text { specialist }\end{array}$ & Specifier & Lead-User \\
\hline $\begin{array}{l}\text { Cus tomer } \\
\text { contribution }\end{array}$ & $\begin{array}{l}\text { Future market } \\
\text { knowledge }\end{array}$ & $\begin{array}{l}\text { Application } \\
\text { knowledge }\end{array}$ & $\begin{array}{c}\text { Complementary } \\
\text { competence and } \\
\text { leveraging capability }\end{array}$ & $\begin{array}{l}\text { Deep R\&D } \\
\text { knowledge }\end{array}$ & $\begin{array}{l}\text { Coming need and } \\
\text { concept ideas }\end{array}$ \\
\hline Rationale & $\begin{array}{c}\text { Integ rate cus tomer to } \\
\text { identify market and } \\
\text { technology } \\
\text { opportunities }\end{array}$ & $\begin{array}{l}\text { Integ rate cus tomer } \\
\text { to select and } \\
\text { improve concepts }\end{array}$ & $\begin{array}{l}\text { Integ rate cus tomer } \\
\text { to conduct leading } \\
\text { innovation project }\end{array}$ & $\begin{array}{c}\text { Integ rate cus tomer } \\
\text { to jointly develop } \\
\text { specification }\end{array}$ & $\begin{array}{c}\text { Integ rate cus tomer } \\
\text { to jointly develop } \\
\text { specification }\end{array}$ \\
\hline $\begin{array}{l}\text { Key issues } / \\
\text { Managerial } \\
\text { challenges }\end{array}$ & $\begin{array}{l}\text { Early in the FFE } \\
\text { Select cus tomer based } \\
\text { on his ability to predict } \\
\text { future markets } \\
\text { requirements } \\
\text { Focused on market } \\
\text { knowledge and generic } \\
\text { technology trends } \\
\text { Consider also } \\
\text { cus tomers' cus tomers }\end{array}$ & $\begin{array}{l}\text { At the end of the FFE } \\
\text { Select cus tomers based } \\
\text { on their experience level } \\
\text { and usage intensity } \\
\text { Focused on specific } \\
\text { application knowledge }\end{array}$ & $\begin{array}{l}\text { Covering most of the } \\
\text { FFE } \\
\text { Select customers or } \\
\text { intermediaries based on } \\
\text { their specific knowledge } \\
\text { necessary to leverage } \\
\text { the suppliers core } \\
\text { competence } \\
\text { Focused on } \\
\text { complementary } \\
\text { knowledge }\end{array}$ & $\begin{array}{l}\text { Focus the later parts of } \\
\text { the FFE } \\
\text { Select cus tomers that } \\
\text { are technology experts } \\
\text { and co-create with them } \\
\text { Focused on core } \\
\text { competence }\end{array}$ & $\begin{array}{l}\text { In the middle of the FFE } \\
\text { Select cus tomers bas ed } \\
\text { on their leading edge } \\
\text { needs and high } \\
\text { motivation } \\
\text { Focused on cus tomer } \\
\text { needs }\end{array}$ \\
\hline Examples & $\begin{array}{c}\text { Bayer Material } \\
\text { Science Creative } \\
\text { Center }\end{array}$ & $\begin{array}{l}\text { Hilti Diamond } \\
\text { Sys tems focus } \\
\text { groups }\end{array}$ & $\begin{array}{l}\text { Zumtobel S taff } \\
\text { s trategic partner } \\
\text { development }\end{array}$ & $\begin{array}{c}\text { EADS As trium ESA } \\
\text { mission projects }\end{array}$ & $\begin{array}{l}3 M \text { Lead-Us er } \\
\text { projects }\end{array}$ \\
\hline
\end{tabular}

Figure 2: Overview early customer integration ECI

\section{Conclusion and Future Directions}

The extensive research in the field of customer integration demonstrates that different ways to consider customers in the product innovation process exist. From the heart of front-end NPD, we introduce ECI as an area of active customer integration that expands the classic Lead User approach in a differentiated way. Depending on the specific contribution customers make to NPD, ECI takes place at different stages in the front-end process with different objectives, intensity, and layout.

Depending on the manufacturer's goals, three main drivers determine the way customers should be integrated: chance orientation, creation orientation, and solution orientation. These drivers lead to four specific customer roles, as our conceptual framework shows. On this foundation, we analyze the respective characteristics and managerial challenges of these early customer roles. In turn, this analysis indicates that though ECI can improve the effectiveness of the innovation process by enabling powerful new knowledge 
creation, its concrete deployment requires careful considerations of the specific customer roles, as well as the entire customer integration process setup and execution.

This preliminary analysis does not address the issue of the concrete shape of companies' ECI processes. However, our research suggests that the manufacturer must first make the basic decision to realize ECI. According to the circumstances, it can select the appropriate ECI mode and customer role that best fits its goals. As a next step, the shape of the ECI process should be worked out on the basis of key layout elements and parameters. These relevant layout elements should be developed in additional research. The relevant contingency factors to be considered include the market environment, the competitive situation of the manufacturer and customer, the product specificity, the level of technologies, customer characteristics, and the company's in-house innovation culture. Our findings fit the broader context of an open innovation paradigm (Chesbrough 2003) that suggests cooperative innovation processes are imperative for success in today's challenging business environment. That is, the careful consideration of the roles and contributions of externals becomes necessary for firms to profit from the knowledge of people outside their borders. For example, software development might be a paragon market in terms of open innovation. Innovation efforts in concert with customers have become the new standard, whether initiated by the manufacturer, as in agile computing situations (e.g., Extreme Programming $\mathrm{XP}$ ), or dominated by an autarky community, as in the successful open source scene (e.g., Mozilla Firefox browser).

In conclusion, the study of ECI attracts increasing attention because of its unexplored potential in terms of customer roles and contributions. In this article, we attempt to lay a base for ECI and relate to its constituents beyond the Lead User concept. As a continuation of this study, further and refined empirical research will help reveal deeper insights into the potential of ECI for a broad set of industries and application fields.

\section{References}

Atuahene-Gima, K. (1995). "An Exploratory Analysis of the Impact of Market Orientation on New Product Performance: A Contingency Approach." Journal of Product Innovation Management 12(4): 275-293.

Atuahene-Gima, K. (1996). "Market Orientation and Innovation." Journal of Product Innovation Management 13(5): 456-457.

Bacon, G. and S. Beckman (1994). "Managing product definition in high-technology industries: A pilot study." California Management Review 36(3): 32.

Brockhoff, K. (2002). Produktinnovation. Handbuch Produktmanagement: Strategieentwicklung - Produktplanung - Organisation - Kontrolle. S. Albers and A. Herrmann. Wiesbaden, Gabler: 1114pp. 
Bruce, M. and W. G. Biemans (1995). Product Development: Meeting the Challenge of the Design Marketing Interface. Chichester, Wiley.

Buergel, H. D. and A. Zeller (1997). "Controlling kritischer Erfolgsfaktoren in der Forschung und Entwicklung." Controlling 9(4): 218-225.

Chesbrough, H. W. (2003). Open Innovation: The New Imperative for Creating and Profiting from Technology. Harvard Business School Press.

Christensen, C. M. (1997). The Innovator's Dilemma. Boston, Harvard Business School Press.

Cooper, R. G. and E. J. Kleinschmidt (1988). Resource Allocation in the New Product Process. Industrial Marketing Management. 17: 249.

Ernst, H. (2001). Erfolgsfaktoren neuer Produkte. Deutscher Universitätsverlag.

Gassmann, O. and B. Gaso (2004). "Insourcing Creativity with Listening Posts in Decentralized Firms." Creativity \& Innovation Management 13(1): 3.

Gebhardt, A. (1996). Rapid Prototyping - Werkzeuge für die schnelle Produktentwicklung. München, Hanser.

Gerpott, T. J. (1998). Strategisches Technologie- und Innovationsmanagement - Eine konzentrierte Einführung. Stuttgart, Schäffer-Poeschel.

Gruner, K. E. (1997). Kundeneinbindung in den Produktinnovationsprozess : Bestandsaufnahme, Determinanten und Erfolgsauswirkungen. Wiesbaden, Gabler.

Gruner, K. E. and C. Homburg (1999). "Innovationserfolg durch Kundeneinbindung. Eine empirische Untersuchung." Zeitschrift für Betriebswirtschaft (1/1999): 119-142.

Henard, D. H. and D. M. Szymanski (2001). "Why Some New Products Are More Successful Than Others." Journal of Marketing Research 38(3): 362.

Herstatt, C. and B. Verworn (2003). Management der frühen Innovationsphasen Grundlagen - Methoden - Neue Ansätze. Wiesbaden, Gabler.

Huber, G. P. (1991). Organizational Learning: The Contributing Processes and the Literatures. Organization Science 2: 88.

Jaworski, B. J. and A. K. Kohli (1993). "Market orientation: Antecedents and consequences." Journal of Marketing 57(3): 53.

Kahn, K. B. (2001). "Market orientation, interdepartmental integration, and product development performance." Journal of Product Innovation Management 18(5): 314323.

Kim, J. and D. Wilemon (2002). "Strategic issues in managing innovation's fuzzy frontend." European Journal of Innovation Management 5(1): 27-39.

Kim, W. C. and R. Mauborgne (1997). Value Innovation: The Strategic Logic of High Growth. Harvard Business Review. 75: 102.

Kirchmann, E. M. W. (1994). Innovationskooperation zwischen Herstellern und Anwendern. Wiesbaden. DUV Deutscher Universitäts-Verlag.

Kleinaltenkamp, M. and B. Dahlke (1998). "Market Orientation and Customer Orientation of Industrial Companies." Thexis (4): 32-37. 
Koen, P., G. Ajamian, et al. (2001). "Providing Clarity and a Common Language to the 'Fuzzy Front End'." Research Technology Management 44(2): 10p.

Kotler, P., D. C. Jain, et al. (2002). Marketing Moves: A New Approach to Profits, Growth \& Renewa. Harvard Business School Press.

Kristensson, P., P. R. Magnusson, et al. (2002). "Users as a Hidden Resource for Creativity: Findings from an Experimental Study on User Involvement." Creativity \& Innovation Management 11(1): 55.

Leonard-Barton, D. E. (1995). Wellsprings of knowledge - building and sustaining the sources of innovation. Boston, MA, Harvard Business School Press.

Lettl, C., Ed. (2004). Die Rolle von Anwendern bei hochgradigen Innovationen. Wiesbaden, Gabler Edition Wissenschaft.

Lilien, G. L., P. D. Morrison, et al. (2002). "Performance Assessment of the Lead User IdeaGeneration Process for New Product Development." Management Science 48(8): 18p.

Lukas, B. A. and O. C. Ferrell (2000). "The Effect of Market Orientation on Product Innovation." Journal of the Academy of Marketing Science 28(2): 239.

Lynn, G. S., J. G. Morone, et al. (1996). "Marketing and discontinuous innovation: The probe and learn process." California Management Review 38(3): 8.

Madhavan, R. and R. Grover (1998). From Embedded Knowledge to Embodied Knowledge: New Product Development as Knowledge Management. Journal of Marketing 62: 2-12.

Murphy, S. A. and V. Kumar (1996). "The role of predevelopment activities and firm attributes in new product success." Technovation 16(8): 431.

Murphy, S. A. and V. Kumar (1997). "The front end of new product development: A Canadian survey." $R \& D$ Management 27(1): 5.

Nonaka, I. and H. Takeuchi (1995). The knowledge creating company. New York, Oxford University Press.

Punch, K. F. (1998). Introduction to Social Research - Quantitative and Qualitative Approaches. London, SAGE Publications.

Rotering, C. (1990). Forschungs- und Entwicklungskooperationen zwischen Unternehmen. Eine empirische Analyse. Stuttgart, Schäffer-Poeschel.

Sakakibara, M. (1997). "Heterogeneity of firm capabilities and cooperative research and development: An empirical examination of motives." Strategic Management Journal 18(S1): 143-164.

Stake, R. E. (1988). Case study methods in educational research: seeking sweet water. Complementary Methods for Research in Education. R. Jaeger. Washington DC, American Educational Research Association: 253-300.

Teichert, T. (1994). Erfolgspotential internationaler F\&E-Kooperationen. Wiesbaden.

von Hippel, E. (1976). "The dominant role of users in the scientific instrument innovation process." Research Policy 5(3): 212-239.

von Hippel, E. (1978). "A customer-active paradigm for industrial product idea generation." Research Policy 7(3): 240-266. 
von Hippel, E. (1986). "Lead Users: A Source of Novel Product Concepts." Management Science 32(7): 791 - 805.

von Hippel, E. (1988). The Sources of Innovation. New York, Oxford University Press.

Yin, R. K. (1994). Case Study Research: Design and Methods. Sage Publications. 